\title{
Educational Federalism in Germany: Foundations of Social Inequality in Education
}

\author{
MARKUS FREITAG ${ }^{*}$ and RAPHAELA SCHLICHT ${ }^{*}$
}

\begin{abstract}
This article applies Fuzzy Set Qualitative Comparative Analysis to examine how sub-national education systems affect the extent of social inequality in education within the German federal states. Variations in educational outcomes between the federal states can be primarily attributed to the strict educational decentralization in Germany. We examine four conditions of regional education systems presumed to be relevant for the extent of social inequality in education: the availability of early childhood education, the development of all-day schools, the onset of tracking to different school types, and the degree of tripartition in secondary education. Altogether, we find systematic relationships between the variation of sub-national education systems and the extent of social inequality in education. The results indicate that well-developed early childhood education is necessary for a low degree of educational inequality. However, educational inequality is not directly related to partisan and socioeconomic determinants.
\end{abstract}

\section{Introduction}

Since the publication of the Program for International Student Assessment (PISA) (Prenzel et al. 2004), the comparative approach to effectiveness of education systems has played a pivotal role in Germany's public affairs. In addition to the achievement of competencies, the high degree of social inequality in education is currently a main focus of political debate. ${ }^{1}$ In general, developed countries condemn socially based educational inequalities; the dependence of educational attainment on social background, rather than on individual capabilities, is judged as wasted human capital (Handl 1985). Moreover, meritocratic values discourage a socially based allocation of public goods and favor instead one based on individual capabilities and effort (Solga 2005). The school systems' capacity to produce social equality, therefore, plays a major role in today's welfare state (Heidenheimer 1973; Schneider and Keesler 2007; Wilensky 1975). Comparative educational evaluations reveal dramatically varying degrees of educational inequality among different political units (Blossfeld and Shavit 1993; Ehmke, Siegle, and Hohensee 2005; Martin et al. 2000).

*University of Konstanz

Konstanzer Online-Publikations-System (KOPS)

URN: http://nbn-resolving.de/urn:nbn:de:bsz:352-opus-108574

URL: http://kops.ub.uni-konstanz.de/volltexte/2010/10857 
Among the Organisation for Economic Co-operation and Development countries, PISA findings show that Germany has one of the most socially selective school systems. Following the publication of PISA 2000 and PISA 2003, UN Special Rapporteur Venor Munoz Villalobos emphasized this awkward situation in Germany's school system while addressing the right to education. In Germany, social background explains $22.8 \%$ of the variance of 15-year-old students' mathematical achievement (Prenzel et al. 2004). By contrast, in Canada, Finland, and Iceland, social background explains only $10 \%$ or less of the variance. These differing educational outcomes require a macro-explanation of social inequality in education. Müller and Pollak $(2004,82)$ regard the education system as one of the institutions mainly responsible for the low level of social mobility in Germany. Although a great deal of micro-sociological and educational research exists on the development of social inequality in education, contributions from the field of political science evaluating the characteristics of the education system remain rather scarce (see Schütz, Ursprung, and Wößmann 2005; von Below 2002).

To fill this research gap, the present study evaluates a variety of political-institutional foundations of educational inequality. German education policies are completely decentralized, speaking to the wide variance in the extent of social inequality of educational achievement among the federal states, as revealed by the PISA-E sub-national comparison (Ehmke, Siegle, and Hohensee 2005). For example, compared with their workingclass counterparts, Bavarian pupils from the highest socioeconomic background quartile are 6.65 times more likely to be enrolled at the Gymnasium; in Brandenburg, this odds ratio is only 2.38. Furthermore, with regard to the German federal states, it is remarkable that educational policies are completely decentralized. Despite the plausible argument of an interrelation between the variation of educational inequality and educational macro-structures on the sub-national level, no scientific investigation of these relations exists (Freitag and Vatter 2008).

Our guiding question concerns the impact of education systems on the extent of social inequality in education. The aim of this study is to identify relevant education policy foundations that produce widely varying degrees of social inequality within the German federal states. We take an initial step to evaluate the effects of regional education policies as well as focus on the performance of the states' education systems. By comparing the federal states on the basis of several educational features, we find meaningful variation along four main dimensions: the extent of early childhood education, the development of all-day schools, the degree of tripartition in secondary school, ${ }^{2}$ and the onset of institutional tracking. These features are often discussed as moderators of social inequality in education in public debates in Germany, as well as in micro-sociological investigations. We assume these factors are able to determine the extent of social inequalities in education at the subnational macro-level. 
To identify relevant educational institutions for varying degrees of social inequality, we apply the Fuzzy Set Qualitative Comparative Analysis (fsQCA) (Ragin 2000). In the current macro-qualitative comparative approach, fsQCA has been gaining in popularity and application (Pennings 2003; Rihoux and Grimm 2006; Schneider and Wagemann 2007; Sager 2005). The approach takes convincing features of multiple conjunctural causation into consideration (Mahoney and Goertz 2006). We expect the degree of social inequality in education to be an effect of complex political-educational configurations rather than a result of single isolated variables. Furthermore, Conjunctural Comparative Methods estimate the outcome of high or low social inequality as a product of several independent explanatory paths.

As a main result, we find limited availability of early childhood education to be sufficient for a high degree of social inequality in education; extensive early childhood education, however, is necessary for a low degree of social inequality within the federal states. Moreover, the combination of a greater provision of early childhood education and a late onset of institutional tracking is sufficient to achieve a low degree of social inequality in education. Surprisingly, the degree of tripartition in secondary school education and the development of the all-day school do not seem to affect the variation of social inequality among the German federal states. The effects of education system conditions are not sensitive to the inclusion of socioeconomic and partisan determinants.

The article is organized as follows: First, we introduce the sociological concept and the measurement of social inequality in Germany, as well as discuss its variation among the 16 federal states. We then discuss our theoretical assumptions about education policy foundations of social inequality and offer a brief description of the school systems in Germany. Third, we illustrate the fuzzy coding of all explanatory conditions and the outcome. The analysis of necessary and sufficient conditions for high as well as low social inequality of education is based on a systematic comparison of education systems in Germany. We conclude with a summary and a discussion of our major findings.

\section{Prevalence of Social Inequality in Education in Germany}

How can social inequality in education be measured? Jacobs (1996) finds three forms of social inequality in education: inequality of educational access, which describes the enrolment disparities of different societal groups in educational institutions; inequality of the educational process, pointing to the disparity in achievement of expertise (e.g., capabilities in math); and inequality of educational outcome, which refers to the opportunities one has in the labor market after completing school. We assume that social inequalities are rooted in the inequalities of educational access 
and process during school education. Social inequalities present during one's school education are presumed to be a foundation for future disadvantages.

But how do we conceptualize social inequality within the German federal states? Social inequalities in Germany arise mainly because of the inequalities of educational access to the different secondary schools: Hauptschule, Realschule, and Gymnasium. In Germany, occupational and post-secondary education opportunities primarily depend on the type of secondary school attended. For example, only those who complete secondary school at a Gymnasium are able to attend a university. Vocational training remains an opportunity for those who attend the other types of secondary schools. The Hauptschule graduation, however, affords the fewest occupational opportunities. It is not the achievement of competencies (inequality of educational process) but rather the access to different school forms (inequality of educational access) that primarily predicts the likelihood of continuing on to post-secondary education and occupational success. We therefore use inequality of access to the Gymnasium as the most significant proxy for social inequality in education in Germany.

In PISA-E 2003, differences between social classes regarding access to the Gymnasium within the federal states are estimated by odds ratios of being enrolled at the Gymnasium (column 2, Table 1). To measure pupils' social background in PISA-E 2003, investigators use an international standardized questionnaire-the Index of Economic, Social, and Cultural

TABLE 1

The Extent of Social Inequality in Education within the German Federal States

\begin{tabular}{lc}
\hline Land & $\begin{array}{c}\text { Outcome: Social Inequality in } \\
\text { Education; Odds Ratios of the } \\
\text { Access to the Gymnasium } \\
\text { (Ehmke, Siegle, and } \\
\text { Hohensee 2005, 262) }\end{array}$ \\
\hline Bource & 6.65 \\
Bavaria (BY) & 6.16 \\
Saxony-Anhalt (ST) & 4.60 \\
Rhineland Palatinate (RP) & 4.40 \\
Baden-Wuerttemberg (BW) & 4.35 \\
North Rhine-Westphalia (NW) & 3.55 \\
Hamburg (HH) & 3.48 \\
Saarland (SL) & 3.47 \\
Mecklenburg-Western Pomerania (MV) & 3.23 \\
Thuringia (TH) & 2.88 \\
Schleswig Holstein (SH) & 2.83 \\
Bremen (HB) & 2.79 \\
Saxony (SN) & 2.71 \\
Hesse (HE) & 2.67 \\
Berlin (BE) & 2.63 \\
Lower Saxony (NI) & 2.38 \\
Brandenburg (BB) &
\end{tabular}


Status (ESCS). It includes indicators for economic, cultural, and social resource items. The odds ratios represent the varying chances of being enrolled at the Gymnasium, as opposed to one of the other school types, for the highest and second-lowest (reference quartile in PISA-E, working class) ESCS quartiles. For example, the value obtained for Bavaria was 6.65, indicating that pupils from the highest socioeconomic background are 6.65 times more likely to attend a Gymnasium than pupils from the second-lowest socioeconomic quartile. This odds ratio is only 2.38 in Brandenburg. How can such differences be explained? In the remainder of this article, we examine explanations referring to characteristics of the German education system. The estimated odds ratios (column 2, Table 1) of attending the Gymnasium, and not one of the other school types, are thus our outcome indicators. ${ }^{3}$

\section{Theoretical Accounts: The Influence of Educational Systems on Social Inequality}

Previous theories on the social inequality in education mainly exist at the micro-sociological level. The explanatory power of both decision theories (Boudon 1973; Goldthorpe 1996) and capital theories (Bourdieu 1983) on the micro-sociological level has been well established in the sociological literature. The key assumption is that individuals weigh the costs, benefits, and risks of different educational alternatives depending on their capital resources (Becker 2003). It is evident that the reproduction of several capital forms from parents to children leads to different premises for successful education (Blossfeld and Shavit 1993; Coleman 1990; DiMaggio 1982; Schimpl-Neimanns 2000; Teachman, Paasch, and Carver 1996). Comparative surveys, however, show varying degrees of social inequality in education between societies.

Empirical education studies consistently refer to potential politicaleducational catalysts of disparities in education (Archer 2005; Boudon 1973). However, systematic and far-reaching comparative explorations of such relationships are rare. Exceptions include the studies by Schütz, Ursprung, and Wößmann (2005) at the international level and von Below's (2002) comparison of the eastern German federal states. At the aggregated level, Schütz, Ursprung, and Wößmann (2005) analyze macrostructural causes of differences among nations regarding social inequality in education. They show repressive influences of early childcare and late tracking on social inequality. All-day school, however, does not affect the degree of social inequality in an international context. Nevertheless, the results do not consider differences among sub-national units. Von Below (2002) classifies the education systems of the eastern German federal states into four categories (traditional-conservative, reformed-conservative, traditional-liberal, and reformed-liberal) and accordingly asks whether the extent of social inequality in education varies among those typologies. The typologies depend on two dimensions: on the content of teaching 
(either traditional or reformed) and on the structure of the systems (either conservative or liberal). Her main finding is that social inequality regarding occupational and educational status is highest in traditionalconservative educational systems and lowest in reformed-liberal educational systems. However, conclusions about the impact of concrete policy effects on social inequality in education are limited. Overall, the sub-national and national comparison of education policies and their outcomes is still in its fledging stages. For this reason, it is not feasible to make reliable predictions about the performance of multiple educational institutions. This study therefore includes several educational conditions ${ }^{4}$ that appear to be relevant for the context of the German federal states. These conditions were primarily selected based on their apparent variation among the German Länder.

We argue that educational institutions are incentives for educational behavior on the macro level. Consequently, they are able to structure the extent of social inequality in education. The following educational institutions are believed to affect the degree of social inequality: the availability of early childhood education, the development of all-day school, the onset of institutional tracking, and the degree of institutional tracking during secondary school (see Table 2).

\section{Availability of Early Childhood Education}

We assume availability of early childhood education reduces the degree of social inequality in education. The effect of an enriched developmental environment in early childhood is evident. Early childhood education is able to act as a surrogate for insufficient capital resources at home (Hillmert 2005; McClelland and Acock 2006). Consequently, class-specific disparities in educational requirements could be evened out prior to primary school. Children who have been socialized exclusively by their parents have lower capacities to internalize external enrichment influences. A limited early childhood education should thus enhance the degree of social inequality on the macro-societal level. Availability of early childhood education in Germany is primarily represented by the number of child care facilities (column 2, Table 2) and the enrollment rates in preschool institutions (column 3, Table 2) in 1994, the relevant year for the PISA-E 2003 population. ${ }^{5}$ Thuringia, for instance, provides child care facilities for $93.14 \%$ of children up to six years of age; Hamburg only offers facilities for $35.87 \%$ of the same age cohort. In Germany, preschool education is provided for those children who do not possess the necessary skills required for entering school. A specific goal of preschool education is to equip all children with the same set of capabilities before entering primary school. Enrollment rates of the cohort of six-year-old pupils in preschool education vary between $0 \%$ in Brandenburg, Bavaria, and Thuringia (preschool education not offered) and $45 \%$ in Hamburg. 
TABLE 2

Raw Data on the Interval Scaled Conditions, Characteristics of Qualitative Conditions, and Sources

\begin{tabular}{|c|c|c|c|c|c|c|c|}
\hline $\begin{array}{l}\text { Federal } \\
\text { State }\end{array}$ & $\begin{array}{l}\text { Ratio of Number of } \\
\text { Child Care Facilities to } \\
\text { Total Population } \\
\text { between } 0 \text { and } \\
6 \text { Years }(\%), 1994 \\
\text { Federal } \\
\text { Statistical } \\
\text { Office }\end{array}$ & $\begin{array}{c}\text { Ratio of pupils } \\
\text { Enrolled in } \\
\text { Pre-School to Total } \\
\text { 6-Year-Old Population } \\
\text { (\%), 1994 } \\
\text { Federal } \\
\text { Statistical } \\
\text { Office }\end{array}$ & $\begin{array}{l}\text { Percentage of Pupils } \\
\text { Enrolled in All-Day } \\
\text { Schools (mean } \\
\text { 2002-2003) } \\
\text { Standing Conference } \\
\text { of German } \\
\text { Educational Ministers }\end{array}$ & $\begin{array}{l}\text { Onset of Tracking, } \\
\text { Legal Regulation, } 1998 \\
\text { School } \\
\text { Educational } \\
\text { Laws }\end{array}$ & $\begin{array}{l}\text { \% of Pupils Enrolled } \\
\text { in Cooperative } \\
\text { Comprehensive } \\
\text { Schools, (mean } \\
\text { 1998-2003) } \\
\text { Federal } \\
\text { Statistical } \\
\text { Office }\end{array}$ & $\begin{array}{c}\% \text { of Pupils Enrolled } \\
\text { in Integrated } \\
\text { Comprehensive } \\
\text { Schools, (mean } \\
1998-2003 \text { ) } \\
\text { Federal } \\
\text { Statistical } \\
\text { Office }\end{array}$ & $\begin{array}{l}\text { Autonomy } \\
\text { of the } \\
\text { Hauptschule, } \\
1998 \\
\text { School } \\
\text { Educational } \\
\text { Laws }\end{array}$ \\
\hline $\mathrm{SH}$ & 39.56 & 19.46 & 4.00 & End of grade $4+$ transition & 0.00 & 6.95 & Unaffiliated \\
\hline $\mathrm{HH}$ & 35.87 & 45.84 & 6.00 & End of grade $4+$ transition & 2.77 & 29.39 & $\begin{array}{l}\text { Allied to further } \\
\text { school types }\end{array}$ \\
\hline NI & 38.93 & 18.46 & 6.80 & End of grade 6 & 0.31 & 4.46 & Unaffiliated \\
\hline $\mathrm{HB}$ & 41.77 & 17.65 & 6.00 & End of grade 6 & 0.00 & 11.14 & Unaffiliated \\
\hline NW & 38.53 & 8.21 & 15.00 & End of grade $4+$ transition & 0.00 & 15.70 & Unaffiliated \\
\hline $\mathrm{HE}$ & 47.68 & 11.97 & 13.70 & End of grade 4 or 6 & 0.00 & 15.94 & $\begin{array}{l}\text { Allied to further } \\
\text { school types }\end{array}$ \\
\hline $\mathrm{RP}$ & 55.16 & 3.61 & $6.40^{\circ}$ & End of grade 4 or 6 & 9.84 & 4.71 & Unaffiliated \\
\hline BW & 55.76 & 7.37 & 6.40 & End of grade 4 & 0.00 & 0.51 & Unaffiliated \\
\hline BY & 45.51 & 0.00 & 2.40 & End of grade 4 & 0.00 & 0.30 & Unaffiliated \\
\hline SL & 51.91 & 5.28 & 4.90 & End of grade 4 + transition & 34.57 & 14.66 & $\begin{array}{l}\text { Allied to further } \\
\text { school types }\end{array}$ \\
\hline $\mathrm{BE}$ & 58.55 & 32.11 & 22.00 & End of grade 6 & 0.00 & 21.07 & Unaffiliated \\
\hline BB & 97.14 & 0.00 & 10.90 & End of grade 6 & 0.00 & 39.44 & Not existent \\
\hline MV & 85.74 & 4.77 & 10.50 & End of grade $4+$ transition & 9.96 & 4.70 & $\begin{array}{l}\text { Allied to further } \\
\text { school types }\end{array}$ \\
\hline $\mathrm{SN}$ & 88.38 & 4.00 & 23.40 & End of grade $4+$ transition & 59.52 & 0.00 & $\begin{array}{l}\text { Allied to further } \\
\text { school types }\end{array}$ \\
\hline ST & 87.33 & 5.30 & 9.80 & End of grade $4+$ transition & 25.78 & 0.93 & $\begin{array}{l}\text { Allied to further } \\
\text { school types }\end{array}$ \\
\hline TH & 93.14 & 0.00 & 26.60 & End of grade 4 & 55.59 & 1.38 & $\begin{array}{l}\text { Allied to further } \\
\text { school types }\end{array}$ \\
\hline
\end{tabular}




\section{Development of All-Day School}

In Germany's public debate, all-day school is often touted as a means to decrease social inequality. Germany's schools, however, are traditionally half-day; children typically leave school around 1 p.m. The Federal Ministry of Education and Research (2003) has led the shift to all-day schools with a $€ 4$ billion investment plan. Decreasing social inequalities in education is an official objective of the federal all-day school treaty. In all-day schools, all pupils, regardless of social background, are socialized in a similar and enriching environment over the period of an entire day. In the half-day school tradition, organization of leisure time completely depends on families. For example, the availability of remedial lessons or participation in enriching extracurricular activities is very much dependent on parents' financial resources. Compared with their wealthier counterparts, children from less well-off families are at a definite disadvantage. Consequently, we expect high degrees of social inequality in federal states that have not yet required the development of all-day schools and minor social disparities where such a school day exists. Because of the strength of the half-day school tradition in Germany, no federal state can boast high enrollment rates for all-day school. However, referring to data from the Kultusministerkonferenz, ${ }^{6}$ all-day school enrollment rates ${ }^{7}$ seem to depend on the regional context (column 4, Table 2). The highest value is found in Thuringia, with $26 \%$ of pupils attending all-day school. Schleswig-Holstein, however, has only a $4 \%$ full-time school enrollment rate.

\section{Onset of Institutional Tracking}

Another characteristic of the German education system is the traditional early institutional tracking of pupils. Pupils are placed in one of three separate, hierarchically ordered educational programs, each with varying academic reputations. The intention of tracking is to create homogeneous classes with respect to student abilities. We assume that an earlier onset of tracking will be associated with more socially biased educational decisions. Uncertainty of one's own educational capabilities is especially high at the beginning of educational careers (Hillmert 2005). Educational decisions for school types will thus depend primarily on parents' educational expectations and less on the children's educational goals or abilities. Lucas (2001, 1646) argues "if students are less dependent on their parents for later transitions, then social background should be less important for determining who receives additional schooling." A pupil's educational decisions are more likely to be made independently when the onset of tracking is delayed. No federal state has completely abolished ${ }^{8}$ the tracking system, but some have mitigated it by postponing its start. In general, the onset of tracking varies between the fourth and sixth grades (column 5, Table 2). Strict early tracking after the fourth grade and without any transition period or revision possibilities takes place in Bavaria, Baden- 
Wuerttemberg, and Thuringia. Hamburg, North Rhine-Westphalia, Mecklenburg Western-Pomerania, Saarland, Saxony, Schleswig Holstein, and Saxony-Anhalt also track after grade four to different graduation programs but offer a legal transition period, making the possibility to revise one's decision more flexible. Six other federal states have introduced the possibility of postponing tracking to the end of grade six. Berlin and Brandenburg have a six-year primary school; Lower Saxony and Bremen have a two-year transition school "Orientierungsstufe" after primary education. All pupils are together until the end of grade six. Special regulation exists in Hesse and in Rhineland-Palatinate. Both federal states allow for two possible onsets of tracking. Pupils who are not tracked after grade four have a possibility of attending a transition school "Orientierungsstufe" until the end of grade six.

\section{Degree of Institutional Tracking}

In addition to the timing of tracking, the degree of tripartition in secondary school education seems also to be a plausible determinant of social inequality. A strict division of pupils into three hierarchically ordered and separate school types (Gymnasium, Realschule, and Hauptschule) is presumed to lead to a high degree of social inequality in education (Saporito and Sohoni 2007). Mobility between school types is thereby limited. A revision of earlier school decisions will not depend on abilities, and later academic achievements are not considered. As indicators for a weak degree of selectivity, the presence of comprehensive schools and a diminished autonomy of the Hauptschule should reduce the degree of inequality. Investigations of the Hauptschule's student body reveal a significant and long-standing concentration of children from disadvantaged social backgrounds (Solga and Wagner 2001). Consequently, the Hauptschule is often seen as a reservoir of social and ethnic minorities that restricts transition to other school types (Ditton 1989). The comprehensive school, on the other hand, circumvents socially selective school decisions by parents or teachers. The degree of tripartition during secondary school is not standardized across all federal states. Some states have made an effort to remove this selectivity by introducing comprehensive schools or by reducing the autonomy of the Hauptschule. Comprehensive schools provide a common curriculum to all pupils in a single school, regardless of their academic abilities. Cooperative comprehensive schools use in-school tracking, despite the fact that all pupils are taught in one common school. Several graduation types are available within the same institution. Integrative comprehensive schools, however, are more farreaching in dissolving tracking: Pupils are not tracked within the school, but are taught together in the same classroom. The enrolment rates for cooperative comprehensive schools ${ }^{9}$ (column 6 , Table 2 ) vary dramatically from $0 \%$ (no cooperative comprehensive schools at all) in SchleswigHolstein, Bremen, North Rhine-Westphalia, Hesse, Baden-Wuerttemberg, 
Bavaria, Berlin, and Brandenburg to $59.52 \%$ in Saxony. The variation concerning integrative comprehensive school enrollment rates ${ }^{10}$ (column 7, Table 2) is less drastic, ranging from $0 \%$ (Saxony) to $21.07 \%$ (Berlin). Two outliers, Hamburg and Brandenburg, have enrollment rates of $29.39 \%$ and $39.44 \%$ for integrated comprehensive schools. This can be explained by the fact that the introduction of integrative comprehensive schools has been much more far-reaching than the introduction of cooperative comprehensive schools. A further attribute of tripartition in secondary education is the status of the Hauptschule (column 8, Table 2). For the year $1998,{ }^{11}$ we are able to identify three regulations referring to the autonomy of the Hauptschule. For example, while no Hauptschule in Brandenburg exists, the Hauptschule is completely autonomous in Bavaria, Baden-Wuerttemberg, Bremen, Berlin, Schleswig-Holstein, Lower Saxony, North Rhine-Westphalia, and Rhineland-Palatinate. The degree of autonomy of the Hauptschule varies between these two extremes. In seven cases (Hesse, Thuringia, Mecklenburg Western-Pomerania, Saarland, Saxony, Saxony-Anhalt, and Hamburg), the Hauptschule exists exclusively in connection to another school form, mainly to the Realschule, or is integrated in cooperative comprehensive schools.

\section{Methods and Data}

We apply a qualitative comparative strategy to identify the aforementioned relationships between the types of the education systems and the extent of social inequality in education. The fsQCA is a methodological tool of macro-comparative research (Ragin 2000). The logic of causal assessment depends on necessary and sufficient conditions. The fsQCA takes several aspects of causal complexity into consideration, making it suitable for answering this question (Mahoney and Goertz 2006): (1) Cases are seen as configurations of their features and the outcome. Therefore, it is expected that combinations of conditions will affect the outcome. Consequently, the effect of a condition may depend on its contextual embedment. (2) Several conditional paths may lead to the outcome. Different cases are thus explained by several sufficient paths (equifinality). We employ this strategy as an acceptable means to tackle our research problem for several reasons: First, our results are bounded by scope. Our hypotheses depend on the scope of the German federal states and are not transferable to a wide universal population. Moreover, we prefer a caseorientation in our research design. We assume that a particular degree of social inequality is initiated by different causal paths in the different case groups.

Fuzzy coding of explanatory conditions and the outcome (Table 3 ) depends on the basic assumptions about set membership in Boolean and Fuzzy logic (Ragin 2000). The membership of each case in a set of conditions may vary between full membership (value 1) and nonmembership (value 0 ) in a set. The value 0.5 describes the crossover point 
TABLE 3

Fuzzy-Set Data Matrix

\begin{tabular}{|c|c|c|c|c|c|}
\hline Cases & $\begin{array}{l}\text { Outcome High } \\
\text { Degree of } \\
\text { Social Inequality } \\
\text { in Education }\end{array}$ & $\begin{array}{l}\text { Underdeveloped } \\
\text { Early Childhood } \\
\text { Education }\end{array}$ & $\begin{array}{l}\text { Underdeveloped } \\
\text { All-Day School }\end{array}$ & $\begin{array}{c}\text { Early } \\
\text { Tracking }\end{array}$ & $\begin{array}{c}\text { Strong } \\
\text { Tripartition }\end{array}$ \\
\hline $\mathrm{SH}$ & 0.28 & 0.20 & 0.92 & 0.80 & 0.73 \\
\hline $\mathrm{HH}$ & 0.65 & 0.00 & 0.79 & 0.80 & 0.05 \\
\hline NI & 0.09 & 0.22 & 0.70 & 0.00 & 0.86 \\
\hline $\mathrm{HB}$ & 0.23 & 0.24 & 0.79 & 0.00 & 0.46 \\
\hline NW & 0.83 & 0.65 & 0.15 & 0.80 & 0.30 \\
\hline $\mathrm{HE}$ & 0.13 & 0.43 & 0.20 & 0.40 & 0.29 \\
\hline$R P$ & 0.87 & 0.83 & 0.75 & 0.40 & 0.75 \\
\hline BW & 0.84 & 0.71 & 0.75 & 1.00 & 1.00 \\
\hline BY & 1.00 & 0.92 & 1.00 & 1.00 & 1.00 \\
\hline SL & 0.63 & 0.83 & 0.87 & 0.80 & 0.16 \\
\hline $\mathrm{BE}$ & 0.11 & 0.00 & 0.00 & 0.00 & 0.16 \\
\hline $\mathrm{BB}$ & 0.00 & 0.04 & 0.34 & 0.00 & 0.00 \\
\hline MV & 0.62 & 0.14 & 0.36 & 0.80 & 0.40 \\
\hline SN & 0.19 & 0.11 & 0.00 & 0.80 & 0.00 \\
\hline ST & 1.00 & 0.12 & 0.41 & 0.80 & 0.28 \\
\hline $\mathrm{TH}$ & 0.55 & 0.06 & 0.00 & 1.00 & 0.00 \\
\hline
\end{tabular}

(c.p.), indicating border between cases that could be "in" or "out" of a set. The transformation of the interval scaled values (Table 2) into a fuzzyvalue scale (Table 3) among these qualitative anchors (Table 4) was undertaken using Ragin's (2007) direct method. Our selection of the qualitative anchors (Table 4) is completely theoretically based. For all our conditions, as well as for the outcome, there is no universal criterion that defines full membership, full non-membership, or the c.p. The distribution of factor values in the German context, therefore, provides information on the judgment of membership for a single case. We used obvious value breaks among the cases to set the three qualitative thresholds. The coding direction of the conditions refers to the hypotheses for the occurrence of "high social inequality." Consequently, the membership of a case in a condition set describes the condition that is assumed to produce high social inequality, while the non-membership is assumed to produce low social inequality. In the following, the rules for threshold setting are specified by the outcome coding (column 2, Table 3): To respect Germany's strong degree of social inequality in education in international comparison, we opted for conservative borderlines for the c.p. concerning the outcome and full and non-membership. The borderlines are thus defined with rather low levels. Only Brandenburg is judged to be fully out of the set "high social inequality in education." This is explained by its outstandingly comparatively low degree of social inequality. Bavaria and SachsenAnhalt, however, cluster next to each other at an extraordinarily high level of social inequality in education. The threshold for full membership must take the prominent role of these two cases into consideration. 
TABLE 4

Three Qualitative Thresholds of the Explanatory Indicators and the Outcome

\begin{tabular}{|c|c|c|c|}
\hline $\begin{array}{l}\text { Interval-Scaled } \\
\text { Indicators of the } \\
\text { Condition and } \\
\text { Outcome Sets }\end{array}$ & $\begin{array}{l}\text { Threshold } \\
\text { Full Non- } \\
\text { Membership }\end{array}$ & $\begin{array}{l}\text { Crossover } \\
\text { Point }\end{array}$ & $\begin{array}{l}\text { Threshold } \\
\text { Full } \\
\text { Membership }\end{array}$ \\
\hline $\begin{array}{l}\text { High social inequality } \\
\text { in education }\end{array}$ & 2.50 & 3.005 & 5.50 \\
\hline $\begin{array}{l}\text { Limited early child } \\
\text { care facilities }\end{array}$ & $95 \%$ & $72.15 \%$ & $40 \%$ \\
\hline $\begin{array}{l}\text { Low participation in } \\
\text { preschool } \\
\text { education }\end{array}$ & $30 \%$ & $10.09 \%$ & $1 \%$ \\
\hline $\begin{array}{l}\text { Underdeveloped } \\
\text { all-day school }\end{array}$ & $20 \%$ & $8.30 \%$ & $3 \%$ \\
\hline $\begin{array}{l}\text { Early tracking to the } \\
\text { tripartite secondary } \\
\text { school education }\end{array}$ & $\begin{array}{l}\text { General } \\
\text { tracking } \\
\text { after } \\
\text { grade } 6\end{array}$ & $\begin{array}{c}\text { Possibility to } \\
\text { track after grade } \\
6\end{array}$ & $\begin{array}{l}\text { General tracking } \\
\text { after grade } 4\end{array}$ \\
\hline $\begin{array}{l}\text { Underdeveloped } \\
\text { cooperative } \\
\text { comprehensive } \\
\text { school (enrolment } \\
\text { rates) }\end{array}$ & $50 \%$ & $15 \%$ & $1 \%$ \\
\hline $\begin{array}{l}\text { Underdeveloped } \\
\text { integrative } \\
\text { comprehensive } \\
\text { school (enrolment } \\
\text { rates) }\end{array}$ & $30 \%$ & $10 \%$ & $1 \%$ \\
\hline $\begin{array}{l}\text { Autonomy of the } \\
\text { Hauptschule }\end{array}$ & No Hauptschule & $\begin{array}{l}\text { Hauptschule } \\
\text { exists only in } \\
\text { conjunction with } \\
\text { further school } \\
\text { types }\end{array}$ & $\begin{array}{l}\text { Complete } \\
\text { autonomy, fully } \\
\text { separate from } \\
\text { further school } \\
\text { types }\end{array}$ \\
\hline
\end{tabular}

The indicators for the autonomy of the Hauptschule and for the onset of tracking were not measured by interval-scaled data but rather by categorical differences among the sub-national education laws. Calibration of fuzzy memberships in the set "autonomous Hauptschule" thus depends on three different categories of Hauptschule regulations: Brandenburg is coded with a 0 because the Hauptschule does not exist. A second category is coded with 0.4 for those cases where the Hauptschule only exists in alliance to other schools: Graduation from the Hauptschule still exists, albeit only in conjunction with other school types, allowing for mobility. Cases with a completely autonomous Hauptschule, however, are coded with a 1. We proceeded similarly, concerning the onset of tracking (column 5, Table 3): Federal states that strictly track pupils after the fourth grade into different school types are coded by 1 (early onset of tracking). Only Bavaria, Baden Wuerttemberg, and Thuringia are assigned to this group. 
The second category comprises states that select after the fourth grade but legally provide for a transition period between the fifth and sixth grades. This regulation should not be overestimated as an instrument to improve social mobility. The reconsideration of the school decision remains very much dependent on individual teachers and parents. Nevertheless, the possibility of revising school decisions after the fourth grade is more flexible than in the first category of states. For this reason, we assigned these states the value 0.8 . Federal states coded with 0 generally select pupils after the sixth grade. In a fourth category, a transition period (Orientierungsstufe) allows for an optional two-year postponement of the school type decision after the fourth grade. These states are coded as 0.4 (Hesse, Rhineland-Palatinate).

The final fuzzy index of availability of early childhood education (column 3, Table 3) was built by AND conjunctions ${ }^{12}$ of several fuzzy indicators. The federal states in each case focus on only one of the two concepts of early childhood education: child care or preschool education. We therefore prefer to include both concepts in an index without weighting their respective importance..$^{13}$ Concerning the degree of tripartition, the index was again built by a Boolean $A N D$ conjunction (column 6, Table 3 ) of fuzzy values for the enrolment rates for integrative and cooperative comprehensive schools and by the autonomy of the Hauptschule. ${ }^{14}$

\section{Identifying Ideal Types of Education Systems}

Table 5 presents the dichotomous ${ }^{15}$ truth table of the four conditions and their sufficiency for the outcome. The truth table rows indicate the ideal types or vector space corners (Schneider and Wagemann 2007). Each case shows a special membership in each vector space corner, with only one best fit. The short-term dichotomization helps to describe commonalities and differences among cases, as well as making limited diversity apparent. Moreover, we are able to observe contradictions regarding the outcome among cases in the same truth table row.

The truth table indicates the empirical evidence of the two extreme types of the fuzzy set vector space (rows 2 and 3): The conjunction of the presence of all four conditions predicted to lead to the outcome "high degree of social inequality" (underdeveloped early childhood education, underdeveloped all-day school, strong tripartition in secondary education, and early tracking) is the best-fitting ideal type for Bavaria and Baden-Wuerttemberg. The high outcome values in those cases (high social inequality in education in both cases $>0.5$ ) support our hypotheses. The extreme pole on the opposite side of the vector space (well-developed early childhood education, well-developed all-day school, weak selection in secondary school education, and late tracking) is covered by Hesse, Berlin, and Brandenburg. In those cases, the outcome (in each case $<0.5$ ) also corresponds to our hypotheses. 
TABLE 5

Dichotomous Truth Table Including the Ideal Types

\begin{tabular}{|c|c|c|c|c|c|c|}
\hline $\begin{array}{l}\text { Under- } \\
\text { developed } \\
\text { Early } \\
\text { Childhood } \\
\text { Education } \\
\text { (CHILD) }\end{array}$ & $\begin{array}{c}\text { Under- } \\
\text { developed } \\
\text { All-Day School } \\
\text { (FULL) }\end{array}$ & $\begin{array}{l}\text { Strong } \\
\text { Selectivity in } \\
\text { Secondary } \\
\text { School } \\
\text { Education } \\
\text { (SELECT) }\end{array}$ & $\begin{array}{l}\text { Early Tracking } \\
\text { into Different } \\
\text { School Types } \\
\text { (TRACK) }\end{array}$ & Cases & $\begin{array}{l}\text { Consistency of } \\
\text { Sufficiency for } \\
\text { Outcome High } \\
\text { Social Inequality } \\
\text { in Education }\end{array}$ & $\begin{array}{l}\text { Consistency of } \\
\text { sufficiency for } \\
\text { outcome low } \\
\text { social inequality } \\
\text { in education }\end{array}$ \\
\hline 0 & 0 & 0 & 1 & $\mathrm{MV}, \mathrm{SN}, \mathrm{ST}, \mathrm{TH}$ & 0.7 & 0.64 \\
\hline 0 & 0 & 0 & 0 & $\mathrm{HE}, \mathrm{BE}, \mathrm{BB}$ & 0.5 & 1003 \\
\hline 1 & 1 & 1 & 1 & BW, BY & 098 & 0.38 \\
\hline 0 & 1 & 0 & 0 & $\mathrm{HB}$ & 0.69 & 0.9 .825 \\
\hline 0 & 1 & 0 & 1 & $\mathrm{HH}$ & 0.92 & 0.65 \\
\hline 0 & 1 & 1 & 0 & NI & 0.63 & 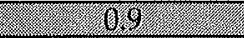 \\
\hline 0 & 1 & 1 & 1 & SH & 0.79 & 0.78 \\
\hline 1 & 0 & 0 & 1 & NW & 0.86 & 0.63 \\
\hline 1 & 1 & 0 & 1 & SL & $088 \%$ & 0.64 \\
\hline 1 & 1 & 1 & 0 & $R P$ & 09 & 0.71 \\
\hline 0 & 0 & 1 & 0 & - & 0.79 & 0.86 \\
\hline 0 & 0 & 1 & 1 & - & 0.92 & 0.71 \\
\hline 1 & 0 & 0 & 0 & - & 0.79 & 0.85 \\
\hline 1 & 0 & 1 & 0 & - & 0.82 & 0.84 \\
\hline 1 & 0 & 1 & 1 & - & 0.9 & 0.71 \\
\hline 1 & 1 & 0 & 0 & - & 0.9 & 0.86 \\
\hline
\end{tabular}

Note: The columns in gray boxes indicate the results are judged as consistently sufficient for the outcome. The columns in white boxes indicate logical remainders are included in the reduction for the most parsimonious solution. 
FIGURE 1

Minimal Description of Limited Diversity

\begin{tabular}{cc}
\hline \multicolumn{2}{c}{ Paths of logical remainders } \\
\hline $\begin{array}{c}\text { well-developed all-day school } \\
\text { AND }\end{array}$ & underdeveloped early childhood education \\
AND
\end{tabular}

Other noteworthy commonalities between cases are found in the first row of the truth table. The conjunction of well-developed early childhood education, well-developed all-day school, weak selection in secondary school, and early tracking is covered by four eastern German federal states (Mecklenburg-Western Pomerania, Saxony, Saxony-Anhalt, and Thuringia), illustrating a strong division of eastern and western education policies. All eastern German states are cumulated in truth table rows that are marked by the absence of the three minimum conditions that are assumed to lead to the outcome "high social inequality." Examining the truth table, only one contradiction among similar cases concerning the outcome appears. In the first row, three cases (Mecklenburg-Western Pomerania, Saxony, and Thuringia) exhibit low social inequality, whereas SaxonyAnhalt has extraordinarily high social inequality. The expectation, however, is a low outcome value. The truth table (Table 5) indicates six out of 16 rows as not empirically evident in the German federal states (rows 11 to 16). These vector space corners are not an ideal type for any case. The Boolean minimization leads to the minimal description of limited diversity in Figure 1. Verbally expressed, federal states that introduced all-day school continued to pursue the high selectivity of the secondary school education.

The reason for this logical remainder might be that a reduction in secondary school selectivity is a necessary first step in reducing inequality before a commitment to all-day school education is enforced. This can be explained by the fact that all-day school entails greater monetary costs. This argument is supported by the historically early introduction of comprehensive schools (in the 1970s) and the overall low level of all-day school development in Germany. Furthermore, no federal state has underdeveloped early childhood education, weak tripartition in secondary education, and late tracking.

\section{Analysis of Necessary and Sufficient Conditions}

The existence of a necessary condition requires a certain presence of the condition if the outcome occurs. In terms of fuzzy logic, this implies that the values of the condition must be equal to or higher than the values of the outcome. The investigation of necessary conditions for the outcome 1 , 
FIGURE 2

Necessity of a High Availability of Early Childhood Education for a Low Degree of Social Inequality in Education

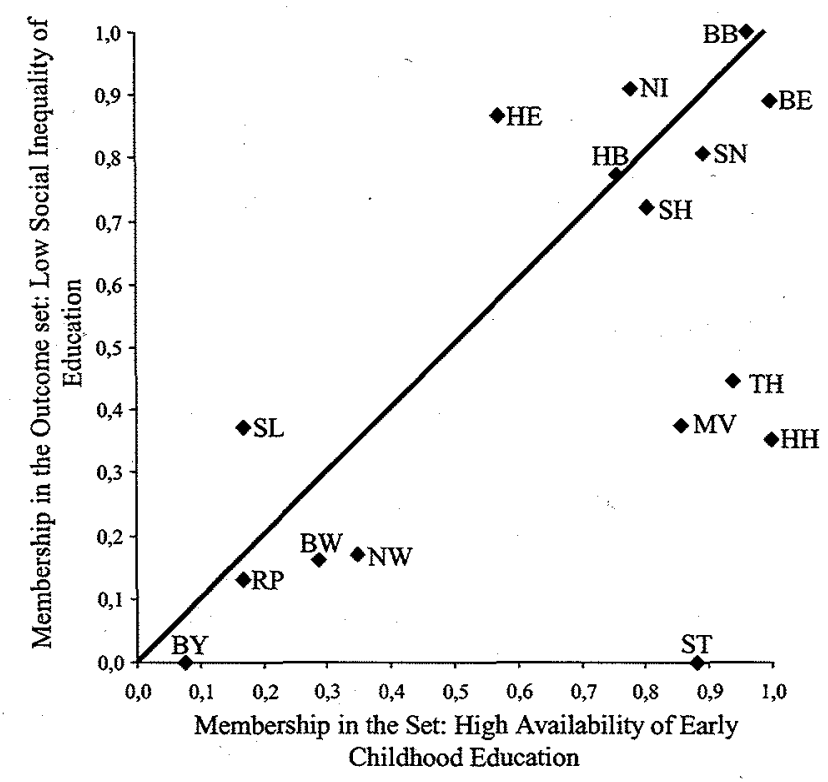

"high social inequality in education," occurs with the conclusion that no policy condition (neither the presence nor the absence) is consistently necessary for a high degree of social inequality. This indicates that social inequality in education is achievable via varying means. Consistency values (Ragin 2006) are all below 0.9 . However, the analysis of necessary conditions for the outcome 0 , "low degree of social inequality," requires a well-developed early childhood education as necessary (Figure 2). We can broadly speculate that highly available child care facilities or high enrollment rates in preschool education must be the first step to achieving social equality in education. While in eastern German federal states the availability of early childcare plays the main role in producing a low degree of social inequality in education, this is substituted by high preschool enrollment rates in western German states. This supports our hypothesis of a strong effect of early childhood education. Early childhood education is a relevant (coverage 0.68 ) and consistently (consistency 0.92 ) necessary condition for a low degree of social inequality in education (Goertz 2006; Ragin 2006).

Sufficient conditions imply the occurrence of the outcome whenever the condition is present. The analysis of sufficient conditions is performed by the Quine McClusky truth table algorithm (Schneider and Wagemann 2007, 63). Truth table rows that are consistently sufficient for the outcome are thereby minimized in favor of more parsimonious solutions. A truth table 
row is sufficient for the outcome when the membership of each case in the particular ideal type is equal to or lower than its membership in the outcome set. For the analysis of sufficient conditions of the outcome 1, "high social inequality," we used a consistency threshold for sufficient rows of $0.85 .{ }^{16}$ We decided to rely upon the most parsimonious solution ${ }^{17}$ (Figure 3 ). The result covers four out of six rows of logical remainders. ${ }^{18}$ The single condition "underdeveloped availability of early childhood education" is designated as sufficient for the outcome "high social inequality in education" (Figure 4, left hand). ${ }^{19}$ Moreover, this condition covers five cases (Rhineland Palatinate, North Rhine-Westphalia, Baden-Wuerttemberg, Bavaria, Saarland). The high social inequality in education is explained solely by these cases' underdeveloped early childhood education. Two further federal states (Hamburg and Saarland) exhibiting high social inequality of education are explained by a conjunctural path (Figure 4, right

FIGURE 3

Minimal Solution of Sufficient Conditions for the Outcome 1 "High Degree of Social Inequality in Education"

\begin{tabular}{|c|c|c|c|c|}
\hline \multirow{2}{*}{ Measures of Fit } & \multicolumn{3}{|c|}{ Susficient conditions } & \multirow{2}{*}{$\begin{array}{l}\text { Outcome } \\
\begin{array}{c}\text { high degree of } \\
\text { social inequality in } \\
\text { editcation }\end{array}\end{array}$} \\
\hline & $\begin{array}{l}\text { underdeveloped early childhood } \\
\text { eaikcation }\end{array}$ & OR & $\begin{array}{c}\text { underdeveloped all-day school } \\
\text { AND } \\
\text { eariy trucking to several school types } \\
\text { AND } \\
\text { wreak tripartite selection }\end{array}$ & \\
\hline Raw Coverage & 0.6 & & 0.35 & \\
\hline Unique Coverage & 0.5 & & 0.15 & \\
\hline Consistency & 0.88 & & 0.88 & \\
\hline Cases Explained & 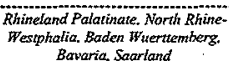 & & Hamburg, Sauriand & \\
\hline Cases not Explained & \multicolumn{3}{|c|}{ Saxony-Anhialt, Thuringia, Mecklenbury-Fessern Pomerania } & \\
\hline $\begin{array}{l}\text { Solution Coosiscency } \\
\text { Solition Coverage }\end{array}$ & & & $\begin{array}{l}0.89 \\
0.75\end{array}$ & \\
\hline
\end{tabular}

FIGURE 4

Sufficient Paths for a High Degree of Social Inequality in Education
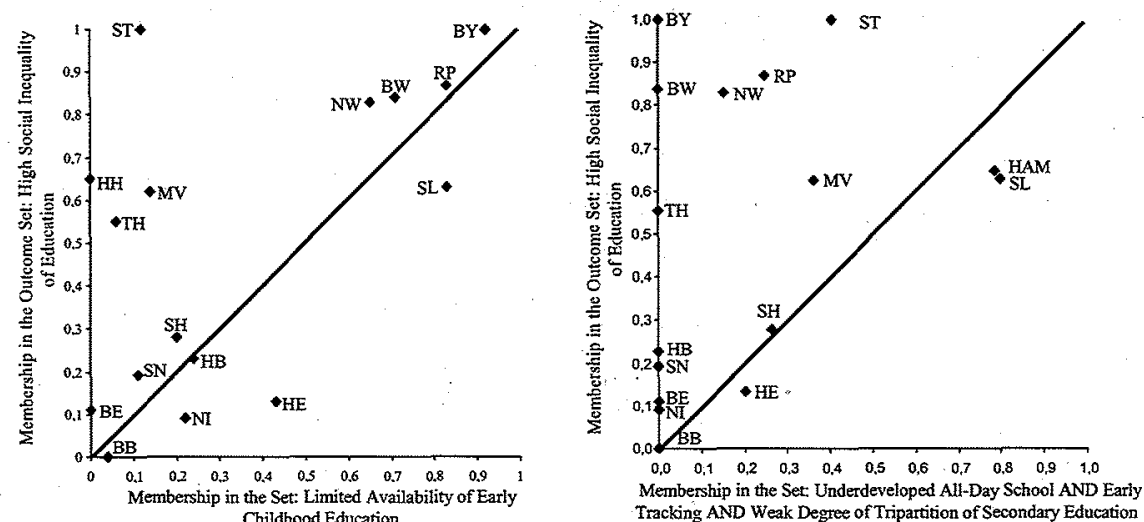
hand) of conditions: underdeveloped all-day school, weak selectivity, and early tracking into different school types. This conjunction does not completely match our assumptions. Weak tripartition is supposed to reduce social inequality instead of promoting it. However, the reliability of this solution path is limited by the quite low raw and unique coverage. ${ }^{20}$ Consequently, we should not overestimate the occurrence of weak tripartition in this sufficient conjunction for high social inequality.

It is also remarkable that three cases (Mecklenburg-Western Pomerania, Saxony-Anhalt, and Thuringia) with a high degree of social inequality cannot be explained by either solution path-neither underdeveloped early childhood education nor the combination of underdeveloped all-day school, early tracking, and weak tripartition. The high degree of inequality in this row runs counter to our assumptions. All these cases are clearly eastern German federal states, suggesting a weak explanatory power of the results for the presence of social inequality in eastern states (Figure 4). The tenuous nature of these results may have much to do with the persistence of instability and extensive reforms during the 1990s. Moreover, it should also be noted that many characteristics of the eastern German Bundesländer changed dramatically after the German reunification in the 1990s.

We used a consistency threshold of $0.9^{21}$ for the minimization of sufficient conditions for low social inequality in education. The most parsimonious solution ${ }^{22}$ makes simplifying assumptions only about one row in the truth table. ${ }^{23}$ This assumption is acceptable because it does not contradict the simplifying assumptions for the outcome 1. A low degree of social inequality within the German federal states is explained by a single twofold combination: high availability of early childhood education and late tracking (Figure 5). Because of its inherent value, those federal states with low degrees of social inequality in education have made noticeable efforts in at least one concept of early childhood education during the early 1990s.

However, the results also show that extensive efforts in early childhood education are not sufficient for a low degree of social inequality in education; late tracking by the tripartite school system is also required. The situation in two Länder (Saxony and Schleswig Holstein) cannot however

\section{FIGURE 5}

Minimal Solution for Sufficient Conditions of the Outcome 0 "Low Degree of Social Inequality in Education"

\begin{tabular}{lcc}
\hline Measures of Fit & Sufficient Conjunctions & Outcome \\
\hline & $\begin{array}{c}\text { well-developed earlychildhood education } \\
\text { ANDD } \\
\text { late tracking to several school types }\end{array}$ & $\begin{array}{c}\text { low degree of } \\
\text { social inequality in education }\end{array}$ \\
\hline Raw Coverage & 0.65 \\
Unique Coverage & 0.65 & \\
Consistency & 0.93 & \\
Cases Explained & Hesse, Berlin, Brandenburg, Bremen, Lower Saxony & \\
Cases not Explained & Saxony, Schleswig Holstein 1 & \\
\hline
\end{tabular}


FIGURE 6

Sufficient Path for a Low Degree of Social Inequality in Education

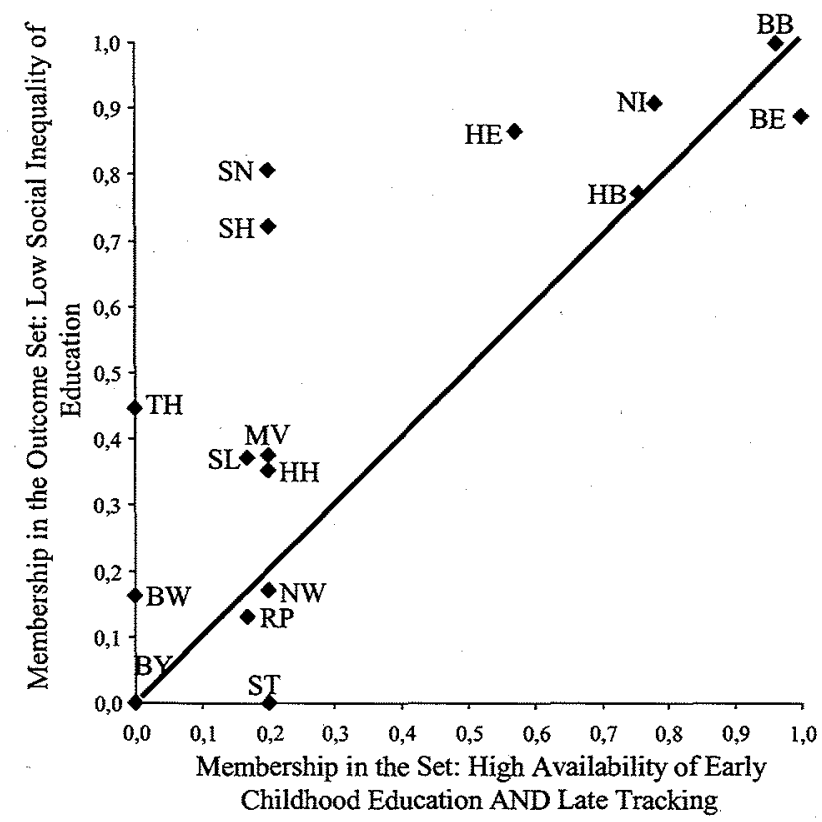

be explained by this combination (Figure 6). Both exhibit a low degree of social inequality in education but do not have a late onset of tracking.

In sum, the degree of social inequality can be explained by education policy features in 11 out of 16 German federal states. Nonetheless, several further macro-conditions could be assumed to be fundamental determinants for a high or low extent of social inequality. Particularly, the degree of general societal inequality, socioeconomic wealth, and the power of left parties are often presumed to determine education policies and their consequences. Even by including one of these non-education policy conditions (social heterogeneity, ${ }^{24}$ average socioeconomic familiar wealth, ${ }^{25}$ and left-party dominance ${ }^{26}$ ) as control conditions for the fsQCA, ${ }^{27}$ it becomes apparent that the effect of education system conditions remains robust. The non-educational characteristics are excluded by the Boolean minimization and do not improve explanatory power (coverage). Several case observations corroborate this impression: For example, both Bremen and Berlin have a low degree of social inequality in education. However, while Bremen shows a very low average socioeconomic familiar status, Berlin is rather wealthy. Regarding left-party dominance, both Bremen and North Rhine-Westphalia are dominated by left parties, but while North Rhine-Westphalia exhibits a high degree of social inequality in education, Bremen remains rather low in this regard. The non-existent relationship between general socioeconomic characteristics and party 
politics on the one hand and the degree of social inequality in education on the other justify our focus on education system conditions.

\section{Conclusion}

Can education policy determine the extent of social inequality in education? The aim of this article was to identify systematic relationships between compositions of education systems and the degree of social inequality within the German federal states. This is a significant step toward evaluating the relevance of education systems and education policy in terms of educational outcomes. We focused on four theoretically relevant factors that vary markedly across the German sub-national units. Moreover, we illustrated systematic communalities and differences regarding education policy in all 16 German federal states. Altogether, we have provided a scientific foundation to the lively debate about the causes of highly differential degrees of social inequality in education among political units.

Our results mainly indicate the relevance of early childhood education for the existence of social inequality in education. As we hypothesized, availability of early childhood education seems to be able to mitigate different preconditions of starting school. An absence of both, widely available early child care and high preschool enrollment rates, is sufficient for a high degree of social inequality in education. In 1994, five federal states had both kinds of early childhood education on only a small scale (Rhineland Palatinate, North Rhine-Westphalia, Baden Wuerttemberg, Bavaria, and Saarland). Moreover, in 2003, all five states had a high degree of social inequality in education within the group of 15-year-old pupils. Accordingly, widely available early childhood education is necessary for a low degree of educational inequality. Without the expansion of either the availability of child care facilities or preschool enrollment rates, no reduction of social inequality seems to be possible. In other words, efforts made in one or more of these education policy features would fall short of its target if no well-developed early childhood education exists.

To some extent, we are able to corroborate the many criticisms of the tripartite secondary school arrangement. In combination with extensive early childhood education, late tracking is an insufficient but necessary parts of unnecessary but sufficient causes (INUS) condition for a low degree of social inequality in education. The institutionalization of late onset tracking to the tripartite school system, combined with highly available early childhood education (either child care facilities or preschool education), is sufficient for a low degree of social inequality in education.

The degree of tripartition of secondary school (a lack of comprehensive schools or a highly autonomous Hauptschule) does not seem to matter. Neither strong nor weak selectivity seems to affect the degree of social inequality in education. We therefore cannot advise completely abolishing the traditional tripartition, but we can certainly support a postponement of tracking to a later point in time. The relevance of the all-day school is not 
completely clear. An underdeveloped all-day school is a part of a conjunction that is sufficient for high social inequality. However, this conjunction does not produce a high explanatory power (coverage). This unclear effect of the all-day school might be due to the general scarcity of such schools in Germany. Enrollment varies between $0 \%$ and 30\% across the federal states. The weak effect nevertheless corresponds to the findings of Schütz, Ursprung, and Wößmann (2005), who, in their international comparison, also do not reveal an effect of the all-day school.

The absent effect of non-educational macro-conditions, that is, left party dominance and socioeconomic factors, justifies our focus on education policy conditions. However, an investigation of the indirect impact party politics have on social inequality in education, via education policy programs and the constitution of particular education systems, would be a promising way to clearly illustrate the education policy decision-making process (Freitag and Bühlmann 2003). Moreover, the Sozialdemokratische Partei Deutschlands (SPD) may not be seen as particularly leftist with regard to its education policies. In the eastern German federal states, other left-leaning traditions and stakeholders likely influenced the legislation on the new education systems and policies after the regime change in 1990.

To conclude, concrete education policies indeed influence the degree of social inequality as an educational outcome. We can recommend a late onset of institutional tracking to hierarchically ordered school types and extensive efforts to make early childhood education widely available. Delaying tracking to later than the end of grade four seems to reduce the dependence of school decisions on social background. Children's capabilities are in fact better assessed at later points in time. Early childhood education, however, seems to be able to balance requirements of school entrance. Our results thus correspond to the work of Schütz, Ursprung, and Wößmann (2005), whose international comparison also identifies late tracking and widely available early childhood education as the two most important determinants of the national degree of educational inequality.

\section{Acknowledgments}

We would like to thank the editors of Governance and the two anonymous referees for their thoughtful comments on previous drafts.

\section{Notes}

1. Social inequality in education refers to the dependence of educational outcomes on an individual's social background, rather than on his or her abilities and capacities.

2. The German school system is characterized by an institutional tracking of secondary school education into three academically ranked school types (Hauptschule, Realschule, and Gymnasium). The graduation certificates of the three school types differ regarding their academic reputation and the resultant occupational and higher educational opportunities. The degree of 
tripartition describes how strictly the three school types are separated and if there are any opportunities (e.g., transition or comprehensive schools) to postpone the tracking.

3. The population of the PISA-E Survey 2003 includes 45,000 15-year-old pupils from all German federal states (Prenzel, Drechsel; and Carstensen 2005).

4. Data are collected for relevant points in time for the population of our outcome proxy social inequality in education: 15-year-old pupils in 2003 (column 2, Table 1.).

5. Data collection 1994: the year prior to when the relevant age cohort of our outcome proxy (15-year-old students in 2003) began primary school.

6. Standing Conference of the Federal Education Ministers.

7. Average of 2002 and 2003 that fits to the secondary school educational period of the reference cohort.

8. Data collection 1998: end of fourth grade for the reference cohort.

9. Average of 1998-2003 that covers to the entire secondary school educational period of the reference cohort.

10. Average of 1998-2003. (See note 9).

11. Earliest entry to the tripartite secondary education for the relevant age cohort of our outcome proxy.

12. With this strategy, we are able to take even the smallest efforts by the states in early childhood education or reduction of tracking into consideration.

13. Only a state that shows underdeveloped early childhood education on both indicators is coded with a high fuzzy value for the early childhood education index. Fuzzy scores make apparent that no state has both a high availability of child care facilities (membership score <0.5) AND a high participation in preschool education (membership score $<0.5$ ). Five states are marked by the presence of low preschool enrolment (membership score >0.5) AND only limited child care facilities (membership score $>0.5$ ). That transfers the overall lacking tradition of early childhood education in Germany.

14. Constructing the index with a Boolean $A N D$ conjunction best respects the highly selective tradition in Germany's secondary education. A federal state with weak selectivity on at least one factor will consequently not be scored with a high selectivity fuzzy value.

15. Fuzzy scores $>0.5$ are transformed to 1 ; fuzzy values $<0.5$ are defined as 0 .

16. The threshold is justified by a large gap below the consistency value of 0.86 .

17. The minimal expression of sufficient conditions for a high degree of social inequality in education obtained by the exclusion of logical remainders is: CHILD $\times$ select $\times$ TRACK (raw coverage 0.28 , unique coverage 0.08 , consistency 0.84 ) + FULL $\times$ select $\times$ TRACK (raw coverage 0.35 , unique coverage 0.15 , consistency 0.88 ) + CHILD $\times$ FULL $\times$ SELECT (raw coverage 0.45, unique coverage 0.3 , consistency 0.94 ). Solution coverage is 0.74 and solution consistency is 0.89 ).

18. Namely, rows 13-16 of the truth table are assumed to lead to a high social inequality in education. These assumptions are plausible, as solution consistency barely decreases, whereas solution coverage increases strongly by including logical remainders.

19. This also is in accordance with De Morgan's law (Schneider and Wagemann 2007), which also infers this statement from the necessity of a welldeveloped early childhood education for low social inequality.

20. Only Hamburg and Saarland are covered by this conjunction, whereas Saarland is also covered by the first solution path.

21. A relevant gap appears below this consistency value.

22. The minimal expression of sufficient conditions for a low degree of social inequality in education obtained by the exclusion of logical remainders is: 
child $\times$ select $\times$ track (raw coverage 0.54 , unique coverage 0.26 , consistency 0.94 ) + child $\times$ FULL $\times$ track (raw coverage 0.38 , unique coverage 0.1 , consistency 0.93 ). Solution coverage is 0.64 and solution consistency is 0.95 .

23. Namely, row 11 is assumed to lead to a low social inequality in education. This is reasonable because it includes the absence of three conditions that are assumed to produce high social inequality. Furthermore, consistency for being sufficient for low social inequality in education is quite high.

24. Standard deviation of the ESCS index (Ehmke, Siegle, and Hohensee 2005, 251) as a proxy for socioeconomic heterogeneity within the federal states.

25. Average ESCS value (Ehmke, Siegle, and Hohensee 2005, 251): Average familiar socioeconomic status within the federal states as a proxy for socioeconomic wealth.

26. Left-party dominance is measured by the number of years an SPD prime minister was in office in relation to the total number of years the federal state has been in existence after World War II.

27. Fuzzy values of the control conditions are calibrated by the direct method (Ragin 2007).

\section{References}

Archer, Margaret. 2005. "Bourdieu's Theory of Cultural Reproduction: French or Universal?" In Pierre Bourdieu 2, ed. Derek Robbins. London: Sage Publications.

Becker, Rolf. 2003. "Educational Expansion and Persistent Inequalities of Education. Utilizing Subjective Expected Utility Theory to Explain Increasing Participation Rates in Upper Secondary School in Federal Republic of Germany." European Sociological Review 19 (1): 1-18.

Blossfeld, Hans-Peter, and Yossi Shavit. 1993. "Dauerhafte Ungleichheiten. Zur Veränderung des Einflusses der Sozialer Herkunft auf die Bildungschancen in Dreizehn Industrialisierten Ländern" [Persistent inequalities: The changing impact of social background on educational opportunities in 13 industrialized nations]. Zeitschrift Für Pädagogik [Journal of pedagogy] 39 (1): 25-52.

Boudon, Raymond. 1973. Education, Opportunity, and Social Inequality. New York: Wiley.

Bourdieu, Pierre. 1983. "Ökonomisches Kapital, Kulturelles Kapital, Soziales Kapital" [Economic capital, cultural capital, social capital] In Soziale Ungleichheiten [Social inequalities], ed. Kreckel Reinhard. Göttingen, Germany: Verlag Otto Schwartz \& Co.

Coleman, James Samuel. 1990. Equality and Achievement in Education. Boulder, CO: Westriew Press.

DiMaggio, Paul. 1982. "Cultural Capital and School Success: The Impact of Status Culture Participation on the Grades of U.S. High School Students" American Sociological Review 47 (2): 189-201.

Ditton, Hartmut. 1989. "Determinanten für elterliche Bildungsaspirationen und für Bildungsempfehlungen des Lehrers" [Determinants of parents' educational aspirations and teacher recommendations]." Empirische Pädagogik [Empirical pedagogy] 3 (3): 215-231.

Ehmke, Timo, Thilo Siegle, and Fanny Hohensee. 2005. "Soziale Herkunft im Ländervergleich" [Familiar social background in the German federal states]. In PISA 2003. Der zweite Vergleich der Lönder in Deutschland-Was wissen und können Jugendliche? [PISA 2003. The second comparison of the Länder in Germany-What do young people know?], eds. Manfred Prenzel, Jürgen Baumert, Werner Blum, Rainer Lehmann, Detlev Leutner, Michael Neubrand, 
Reinhard Pekrun, Jürgen Rost, and Ulrich Schiefele. Münster, Germany: Waxmann.

Federal Ministry of Education and Research. 2003. "Ganztagschule. Zeit für mehr" [All-day school. Time for more]. (http:/ /www.bmbf.de/pub/ganztagsschulenzeit_fuer_mehr.pdf) (September 10, 2008).

Freitag, Markus, and Marc Bühlmann. 2003. "Die Bildungsfinanzen der Schweizer Kantone. Der Einfluss Sozioökonomischer Bedingungen, Organisierter Interessen und Politischer Institutionen auf die Bildungsausgaben im Kantonalen Vergleich" [Determinants of education finance in the Swiss cantons. A comparative perspective]. Swiss Political Science Review 9 (1): 139168.

Freitag, Markus, and Adrian Vatter, eds. 2008. Die Demokratien der Bundesländer. Politische Institutionen im Vergleich. Mit einem Vorwort von Arend Lijphart [The democracies of the German Länder. A comparison of political institutions. including a preface of Arend Ljiphart]. Opladen, Germany: Barbara Budrich

Goertz, Gary. 2006. "Assessing the Trivialness, Relevance, and Relative Importance of Necessary or Sufficient Conditions in Social Science." Studies in Comparative International Development 41 (2): 88-109.

Goldthorpe, John H. 1996. "Class Analysis and the Reorientation of Class Theory: The Case of Persisting Differentials in Educational Attainment." British Journal of Sociology 47 (3): 481-501.

Handl, Johann. 1985. "Mehr Chancengleichheit im Bildungssystem." [Equal opportunities in the education systems] Kölner Zeitschrift für Soziologie und Sozialpsychologie [Cologne journal of sociology and social psychology] 37. (4): 698-722.

Heidenheimer, Arnold J. 1973. "The Politics of Public Education, Health and Welfare in the USA and Western Europe: How Growth and Reform Potentials Have Differed." British Journal of Political Science 3 (3): 315-340.

Hillmert, Steffen. 2005. "Bildungsentscheidungen und Unsicherheit. Soziologische Aspekte eines vielschichtigen Zusammenhangs" [Educational decisions and uncertainty: Sociological aspects of a complex relationship]." Zeitschrift für Erziehungswissenschaft [Journal of educational science] 8 (2): 173-186.

Jacobs, Jerry A. 1996. Gender Inequality and Higher Education. Annual Review of Sociology 22: 153-185.

Lucas, Samuel R. 2001. "Effectively Maintained Inequality: Education Transitions, Track Mobility, and Social Background Effects." American Journal of Sociology 106 (6): 1642-1690.

Mahoney, James, and Gary Goertz. 2006. "A Tale of Two Cultures: Contrasting Quantitative and Qualitative Research." (http://www.compasss.org/ MahoneyGoertz2006.pdf) (September 10, 2008).

Martin, Michael O., Ina V.S. Mullis, Eugenio J. Gonzalez, Kelvin D. Gregory, Teresa A. Smith, Steven J. Chrostowski, Robert A. Garden, and Kathleen M. O'Connor. 2000. TIMSS 1999. International Science Report. Findings from IEA's Repeat of the Third International Mathematics and Science Study at the Eighth Grade. Boston: International Study Center Lynch School of Education.

McClelland, Megan M., and Alan C. Acock. 2006. "The Impact of Kindergarten Learning-Related Skills on Academic Trajectories at the End of Elementary School." Early Childhood Research Quarterly 21 (4): 471-490.

Müller, Walter, and Reinhard Pollak 2004. "Social Mobility in West Germany: The Long Arms of History Discovered?" In Social Mobility in Europe, ed. Richard Breen. Oxford, UK: Oxford University Press, 77-113.

Pennings, Paul. 2003. "Beyond Dichotomous Explanations: Explaining Constitutional Control of the Executive with Fuzzy-Sets." European Journal of Political Research 42 (4): 541-567. 
Prenzel, Manfred, Jürgen Baumert, Werner Blum, Rainer Lehmann, Detlev Leutner, Michael Neubrand, Reinhard Pekrun, Hans-Günter Rolff, Jürgen Rost, and Ulrich Schiefele., eds. 2004. PISA 2003. Der Bildungsstand der Jugendlichen in Deutschland-Ergebnisse des zweiten internationalen Vergleichs [Educational background of German youth: Results of the second international comparison. Münster, Germany: Waxmann.

Prenzel, Manfred, Barabara Drechsel, and Claus Carstensen. 2005. "Einführung in den Ländervergleich PISA 2003". [Introduction to the comparison of the federal states-PISA 2003]. In PISA 2003. Der zweite Vergleich der Länder in Deutschland-Was wissen und können Jugendliche? [PISA 2003. The second comparison of the Länder in Germany-What do young people know?], eds. Manfred Prenzel, Jürgen Baumert, Werner Blum, Rainer Lehmann, Detlev Leutner, Michael Neubrand, Reinhard Pekrun, Jürgen Rost, and Ulrich Schiefele. Münster, Germany: Waxmann.

Ragin, Charles C. 2000. Fuzzy-Set Social Science. Chicago: University of Chicago Press.

- 2006. "Set Relations in Social Research: Evaluating Their Consistency and Coverage." Political Analysis 14 (3): 291-310.

- 2007. "Fuzzy Sets: Calibration versus Measurement." (http:// www.u.arizona.edu/ cragin/fsQCA/download/Calibration.pdf) (September 10, 2008).

Rihoux, Benoit, and Heike Grimm., eds. 2006. Innovative Comparative Methods for Policy Analysis. Heidelberg, Germany: Springer.

Sager, Fritz. 2005. "Metropolitan Institutions and Policy Coordination. The Integration of Land Use and Transport Policies in Swiss Urban Areas." Governance. An International Journal of Policy, Administration, and Institutions 18 (2): 227-256.

Saporito, Salvatore, and Deenesh Sohoni. 2007. "Mapping Educational Inequality: Concentrations of Poverty among Poor and Minority Students in Public Schools." Social Forces 85 (3): 1227-1253.

Schimpl-Neimanns, Bernhard. 2000. "Soziale Herkunft und Bildungsbeteiligung" [Familiar social background and educational attendance]. Kölner Zeitschrift für Soziologie und Sozialpsychologie [Cologne journal of sociology and social psychology] 52 (4): 636-669.

Schneider, Barbara L., and Venessa A. Keesler. 2007. "School Reform 2007: Transforming Education into a Scientific Enterprise." Annual Review of Sociology 33 (1): 197-217.

Schneider, Carsten Q., and Claudius Wagemann. 2007. Qualitative Comparative Analysis (QCA) und fs/QCA: Ein Lehrbuch für Anwender und jene, die es werden wollen" [QCA and fs /QCA: A textbook for users and those who strive to be] Leverkusen, Germany: Budrich, Barbara.

Schütz, Gabriela, Heinrich Ursprung, and Ludger Wößmann. 2005. "Education Policy and Equality of Opportunity." (http://www.cesifo-group.de/portal/ page? pageid =36,425831\&_dad=portal\&_schema=PORTAL) (September 10, 2008).

Solga, Heike. 2005. Meritokratie-die Moderne Legitimation Ungleicher Bildungschancen [Meritocracy-The modern legitimation of unequal education opportunities]. In Institutionalisierte Ungleichheiten [Institutionalized inequalities], eds. Peter A. Berger and Heike Kahlert. Weinheim und München, Germany: Juventa.

Solga, Heike, and Sandra Wagner. 2001. "Paradoxie der Bildungsexpansion. Die doppelte Benachteiligung von Hauptschülem" [The paradox of education expansion: The twofold discrimination of the Hauptschul attendants]. Zeitschrift für Erziehungswissenschaft [Journal of educational science] 4 (1): 107129. 
Teachman, Jay D., Kathleen Paasch, and Karen Carver. 1996. "Social Capital and Dropping Out of School Early." Journal of Marriage and the Family 58 (3): 773783.

von Below, Susanne, 2002. Bildungssysteme und soziale Ungleichheit. Das Beispiel der neuen Bundesländer [Education systems and social inequality: The example of the new German federal states]. Opladen, Germany: Leske + Budrich.

Wilensky, Harold L. 1975. The Welfare State and Equality. Structural and Ideological Roots of Public Expenditures. Berkeley, CA and Los Angeles: University of California Press. 